Wright State University

CORE Scholar

3-1-2007

\title{
The Effect of Si Doping on the Electrical Properties of B12As2 Thin Films on (0001) 6H-SiC Substrates
}

Zhou Xu

J. H. Edgar

David C. Look

Wright State University - Main Campus, david.look@wright.edu

S. Baumann

R. J. Bleiler

See next page for additional authors

Follow this and additional works at: https://corescholar.libraries.wright.edu/physics

Part of the Physics Commons

\section{Repository Citation}

Xu, Z., Edgar, J. H., Look, D. C., Baumann, S., Bleiler, R. J., Wang, S. H., \& Mohney, S. E. (2007). The Effect of Si Doping on the Electrical Properties of B12As2 Thin Films on (0001) 6H-SiC Substrates. Journal of Applied Physics, 101 (5), 53710.

https://corescholar.libraries.wright.edu/physics/157

This Article is brought to you for free and open access by the Physics at CORE Scholar. It has been accepted for inclusion in Physics Faculty Publications by an authorized administrator of CORE Scholar. For more information, please contact library-corescholar@wright.edu. 


\section{Authors}

Zhou Xu, J. H. Edgar, David C. Look, S. Baumann, R. J. Bleiler, S. H. Wang, and S. E. Mohney 


\title{
The effect of Si doping on the electrical properties of $B_{12} A s_{2}$ thin films on (0001) $6 \mathrm{H}$-SiC substrates
}

\author{
Zhou Xu and J. H. Edgar ${ }^{\text {a) }}$ \\ Department of Chemical Engineering, Kansas State University, Manhattan, Kansas 66506 \\ D. C. Look \\ Semiconductor Research Center, Wright State University, Dayton, Ohio 45435 \\ S. Baumann and R. J. Bleiler \\ Evans Analytical Group, 425 Round Rock West Drive, Suite 100, Round Rock, Texas 78681
}

S. H. Wang and S. E. Mohney

Department of Materials Science and Engineering, The Pennsylvania State University, University Park, Pennsylvania 16802 and Materials Research Institute, The Pennsylvania State University, University Park, Pennsylvania 16802

(Received 1 November 2006; accepted 20 December 2006; published online 12 March 2007)

The ability to control the resistivity of the wide band gap semiconductor $\mathrm{B}_{12} \mathrm{As}_{2}$ by doping with silicon was verified. The electrical properties of nominally undoped and Si-doped rhombohedral $\mathrm{B}_{12} \mathrm{As}_{2}$ thin films on semi-insulating $6 \mathrm{H}$-SiC (0001) substrates prepared by chemical vapor deposition were subjected to Hall effect measurements. Varying the Si concentration in the $\mathrm{B}_{12} \mathrm{As}_{2}$ thin films from $7 \times 10^{18}$ to $7 \times 10^{21}$ at. $/ \mathrm{cm}^{3}$ (as measured by secondary ion mass spectrometry) decreased the resistivities of the $p$-type $\mathrm{B}_{12} \mathrm{As}_{2}$ films from $2 \times 10^{5}$ to $10 \Omega \mathrm{cm}$. The resistivities of the $\mathrm{B}_{12} \mathrm{As}_{2}$ films were decreased by one to two orders of magnitude after rapid thermal annealing for $30 \mathrm{~s}$ in argon. The spatial distribution of the hydrogen concentration was measured before and after annealing. No changes were detected, casting doubt on hydrogen as being the cause for the change in the resistivities of the $\mathrm{B}_{12} \mathrm{As}_{2}$ films with annealing. (C) 2007 American Institute of Physics.

[DOI: $10.1063 / 1.2437687$ ]

\section{INTRODUCTION}

$\mathrm{B}_{12} \mathrm{As}_{2}$ is a rarely studied refractory wide band gap semiconductor $\left(E_{g}=3.48 \mathrm{eV}\right) .{ }^{1}$ It is one of the several boronrich solids based on the $\alpha$-rhombohedral boron structure, in which the boron is present in 12-boron-atom icosahedral clusters. These boron icosahedra form a rhombohedral unit cell with the space group $R \overline{3} m .{ }^{2,3}$ For $\mathrm{B}_{12} \mathrm{As}_{2}$, the two arsenic atoms bond together and span the body diagonal of the rhombohedron by bonding with the neighboring boron icosahedra. ${ }^{4,5}$ The unusual structure of $\mathrm{B}_{12} \mathrm{As}_{2}$ imparts it with the ability to self-heal from radiation damage. ${ }^{6}$ Because of this self-healing ability, $\mathrm{B}_{12} \mathrm{As}_{2}$ is a potential candidate for beta cells, devices capable of directly converting nuclear to electrical energy. ${ }^{7}$

Recently, there have been several reports on the morphology, orientation, and defects present in $\mathrm{B}_{12} \mathrm{As}_{2}$ thin films deposited on (0001) $6 \mathrm{H}$-SiC substrates by chemical vapor deposition (CVD). ${ }^{8-11}$ The resulting films are highly oriented with the [111] direction of the $\mathrm{B}_{12} \mathrm{As}_{2}$ film parallel to the [0001] direction of the $6 \mathrm{H}-\mathrm{SiC}$ substrate. The $\mathrm{B}_{12} \mathrm{As}_{2}$ thin films contain a high density of translational and rotational structural variants as a consequence of the different rotational symmetries and lattice constants of the film and substrate.

There have been very few reports on the electrical properties of $\mathrm{B}_{12} \mathrm{As}_{2}{ }^{3}$ Most boron-rich semiconductor com-

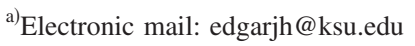

pounds exhibit exclusively $p$-type conductivity. The maximum reported hole mobility for the analogous compound $\mathrm{B}_{12} \mathrm{P}_{2}$ is $100 \mathrm{~cm}^{2} / \mathrm{Vs}$ (Ref. 12) and the value for $\mathrm{B}_{12} \mathrm{As}_{2}$ may be expected to be similar. As part of the studies on metal contacts to $\mathrm{B}_{12} \mathrm{As}_{2}$, Wang et al. ${ }^{13}$ observed a large drop in the resistivity of $\mathrm{B}_{12} \mathrm{As}_{2}$ thin films on $6 \mathrm{H}$-SiC after annealing in argon at $600{ }^{\circ} \mathrm{C}$ for $30 \mathrm{~s}$. They speculated that this change might be due to the release or redistribution of hydrogen in the films.

Recently, Emin ${ }^{14}$ predicted that it should be possible to modulate the resistivity of $\mathrm{B}_{12} \mathrm{As}_{2}$ by doping it with silicon. Since silicon has one fewer valence electron than arsenic, replacing an arsenic atom with a silicon atom in $\mathrm{B}_{12} \mathrm{As}_{2}$ will remove an electron from a bonding state and introduce a hole in the band of states associated with the internal bonding of the boron icosahedra. ${ }^{14}$ In this manner, the hole concentration should increase with $\mathrm{Si}$ doping and consequently the resistivity of $\mathrm{B}_{12} \mathrm{As}_{2}$ should decrease.

This study was undertaken with two goals: to test whether silicon is an effective $p$-type dopant in $\mathrm{B}_{12} \mathrm{As}_{2}$ and to determine if changes in the hydrogen concentration are responsible for the effects of annealing on the $\mathrm{B}_{12} \mathrm{As}_{2}$ resistivity. The results of intentionally doping $\mathrm{B}_{12} \mathrm{As}_{2}$ with silicon and its effects on the electrical properties are described. Secondary ion mass spectrometry measurements were taken to accurately measure the concentration of silicon incorporated and to make sure that the background carbon and oxygen concentrations were low and relatively constant, and would not affect the electrical property measurements. The hydro- 
TABLE I. Description of the $\mathrm{B}_{12} \mathrm{As}_{2}$ samples.

\begin{tabular}{|c|c|}
\hline Sample No. ${ }^{\text {a }}$ & Description \\
\hline S1 & A pure $\mathrm{B}_{12} \mathrm{As}_{2}$ film \\
\hline $\mathrm{S} 2$ & A Si-doped $\mathrm{B}_{12} \mathrm{As}_{2}$ film, $10 \mathrm{SCCM} \mathrm{SiH} 4$ \\
\hline S3 & A Si-doped $\mathrm{B}_{12} \mathrm{As}_{2}$ film, $50 \mathrm{SCCM} \mathrm{\textrm {SiH } _ { 4 }}$ \\
\hline S4 & A Si-doped $\mathrm{B}_{12} \mathrm{As}_{2}$ film, $90 \mathrm{SCCM} \mathrm{\textrm {SiH } _ { 4 }}$ \\
\hline S5 & $\begin{array}{l}\text { A multiple layer-doped } \mathrm{B}_{12} \mathrm{As}_{2} \text { film with various } \mathrm{SiH}_{4} \\
\text { flow rates. The first layer was an undoped } \mathrm{B}_{12} \mathrm{As}_{2} \text { buffer } \\
\text { layer for } 20 \text { mindeposition, the second was } 10 \mathrm{~min} \\
\text { doping at } 90 \mathrm{SCCM} \mathrm{SiH}_{4} \text { flow rate, the third was } \\
10 \text { min doping at } 50 \mathrm{SCCM} \mathrm{SiH}_{4} \text { flow rate, the fourth } \\
\text { was } 10 \text { min doping at } 10 \mathrm{SCCM} \mathrm{SiH}_{4} \text { flow rate, and last } \\
\text { layer was another undoped } \mathrm{B}_{12} \mathrm{As}_{2} \text { layer for } 10 \text { min } \\
\text { deposition. }\end{array}$ \\
\hline S6 & A pure $\mathrm{B}_{12} \mathrm{As}_{2}$ film, annealed \\
\hline S7 & A Si-doped $\mathrm{B}_{12} \mathrm{As}_{2}$ film, $20 \mathrm{SCCM} \mathrm{SiH}$, annealed \\
\hline S8 & A Si-doped $\mathrm{B}_{12} \mathrm{As}_{2}$ film, $10 \mathrm{SCCM} \mathrm{SiH}_{4}$, annealed \\
\hline
\end{tabular}

${ }^{a}$ All the samples are textured polycrystalline with a $c$-axis orientation as $\mathrm{B}_{12} \mathrm{As}_{2}(0001) \| 6 H-\mathrm{SiC}(0001)$.

gen concentration in the $\mathrm{B}_{12} \mathrm{As}_{2}$ films was measured before and after annealing to determine if changes in its concentration occurred.

\section{EXPERIMENT}

Before deposition, the silicon-face, semi-insulating onaxis $6 H$-SiC (0001) substrates were prepared as follows. The substrates were dipped into a $48 \%$ HF solution for $5 \mathrm{~min}$, ultrasonically cleaned using acetone and methanol, and dried with filtered nitrogen before loading into the horizontal coldwall CVD reactor. The substrates were placed inside a hollow boron nitride coated graphite susceptor. The gaseous precursors were $1 \% \mathrm{~B}_{2} \mathrm{H}_{6}$ in $\mathrm{H}_{2}$ and $2 \% \mathrm{AsH}_{3}$ in $\mathrm{H}_{2}$, and the dopant was 100 ppm $\mathrm{SiH}_{4}$ in $\mathrm{H}_{2}$. The flow rates of $\mathrm{B}_{2} \mathrm{H}_{6}$ and $\mathrm{AsH}_{3}$ source gases were 10 and 100 SCCM (SCCM denotes standard cubic centimeters per minute at STP), respectively for a gas phase As/B ratio of 10. For Si-doped samples, the flow rates of $\mathrm{SiH}_{4}$ were varied in the range from 10 to $90 \mathrm{SCCM}$, for a maximum $\mathrm{Si} / \mathrm{B}$ ratio of 0.045 . Palladium membrane purified hydrogen was used as the carrier gas with a constant flow rate of 2.5 SLM (SLM denotes standard liters per minute). For this study, all films were deposited at $1250{ }^{\circ} \mathrm{C}$ (as measured by a thermocouple) in contrast to our earlier study, which used $1450{ }^{\circ} \mathrm{C}$. ${ }^{10}$ The reactor pressure during deposition was fixed at 500 torr. Generally the deposition time was $1 \mathrm{~h}$.

Table I provides descriptions of the eight samples discussed in this paper. Seven samples were single layers each with a different silicon concentration. Sample S5 consisted of five layers, with a different $\mathrm{Si}$ concentration in each layer. Samples S6, S7, and S8 were rapid thermally annealed at $600{ }^{\circ} \mathrm{C}$ for $30 \mathrm{~s}$ in argon.

Hall effect measurements were taken before and after annealing to study the annealing effects on the electrical properties of the $\mathrm{B}_{12} \mathrm{As}_{2}$. The measurements were performed at room temperature in the dark with an Accent model 5500 system, using a magnetic field strength of $5 \mathrm{kG}$. Indium con-

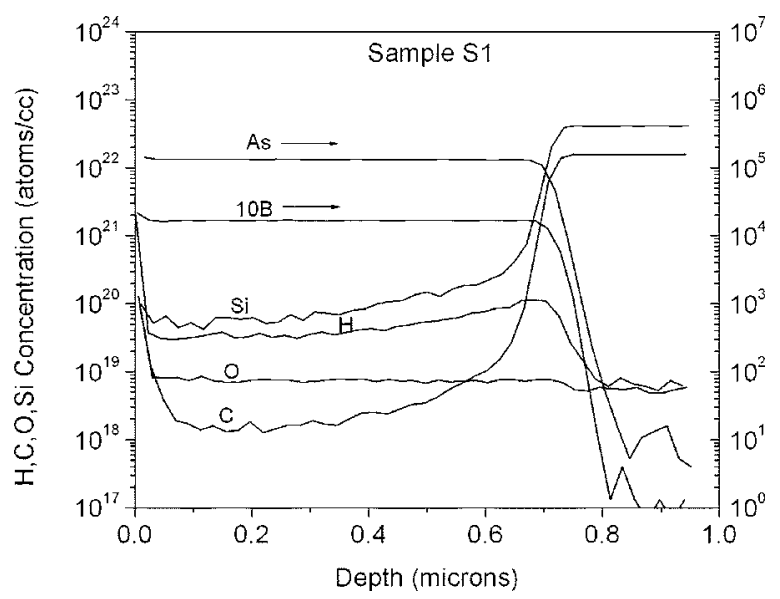

FIG. 1. SIMS profiles of $\mathrm{H}, \mathrm{C}, \mathrm{O}$, and $\mathrm{Si}$ impurities in an undoped $\mathrm{B}_{12} \mathrm{As}_{2}$ thin film.

tacts were soldered on the corners of square samples and the current-voltage characteristics were Ohmic at the current levels used for the study.

The elementary concentrations of $\mathrm{H}, \mathrm{C}, \mathrm{O}$, and Si were measured by secondary ion mass spectrometry (SIMS) and Rutherford backscattering spectrometry/hydrogen forward scattering (RBS/HFS) by the Evans Analytical Group. RBS/ HFS was utilized to accurately measure the hydrogen concentration in three samples since no standards were available to accurately calibrate the hydrogen SIMS profiles. The SIMS measurements of the impurity concentrations in the $\mathrm{B}_{12} \mathrm{As}_{2}$ were calibrated in two ways. The carbon, oxygen, and silicon concentrations were calibrated using a $\mathrm{B}_{12} \mathrm{As}_{2}$ sample, which had been implanted with these impurities. For hydrogen, a calibration was established using the results from RBS/HFS, which provides an absolute measure of hydrogen. The Si concentration was also measured by RBS/ HFS on selected samples and was used to confirm the SIMS Si calibration.

The detection limits for SIMS analysis for carbon, oxygen, and silicon in the $\mathrm{B}_{12} \mathrm{As}_{2}$ layers were $1 \times 10^{18}, 5$ $\times 10^{18}$, and $1 \times 10^{17}$ at. $/ \mathrm{cm}^{3}$, respectively. The detection limit for hydrogen using RBS/HFS was 0.1 at. $\%$. The detection limits were determined by analyzing a piece of float zone silicon under identical conditions employed for the analysis of the $\mathrm{B}_{12} \mathrm{As}_{2}$ samples. The $\mathrm{C}, \mathrm{O}$, and $\mathrm{H}$ concentrations in a float zone silicon sample were $2.2 \times 10^{17}, 2.1$ $\times 10^{18}$, and $1.5 \times 10^{18}$ at. $/ \mathrm{cm}^{3}$, respectively. The concentrations of the impurities in the $\mathrm{B}_{12} \mathrm{As}_{2}$ film were above these detection limits and hence measurable. This assumes that the sticking coefficients for the residual gases are similar between $\mathrm{Si}$ and $\mathrm{B}_{12} \mathrm{As}_{2}$.

\section{RESULTS AND DISCUSSION}

\section{A. Impurity concentrations $(\mathrm{H}, \mathrm{C}, \mathrm{O}$, and $\mathrm{Si})$ in pure and Si-doped $\mathrm{B}_{12} \mathrm{As}_{2}$ films}

Figure 1 shows the SIMS profiles of $\mathrm{H}, \mathrm{C}, \mathrm{O}$, and $\mathrm{Si}$ impurities in a $0.7 \mu \mathrm{m}$ nominally undoped $\mathrm{B}_{12} \mathrm{As}_{2}$ film $(\mathrm{S} 1)$. The $\mathrm{H}, \mathrm{C}, \mathrm{O}$, and $\mathrm{Si}$ concentrations are plotted with a logarithmic concentration scale $\left(\right.$ at. $\left./ \mathrm{cm}^{3}\right)$ versus depth. The B 


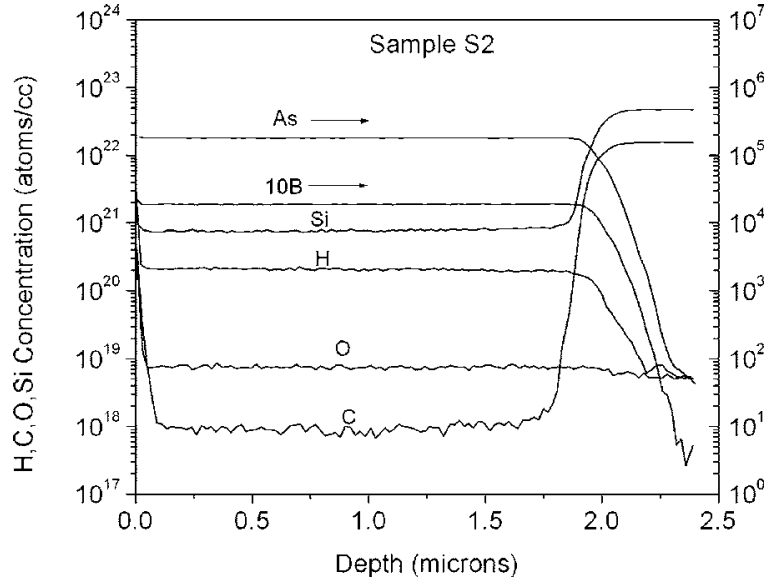

FIG. 2. SIMS profiles of $\mathrm{H}, \mathrm{C}, \mathrm{O}$, and $\mathrm{Si}$ impurities in a Si-doped $\mathrm{B}_{12} \mathrm{As}_{2}$ thin film at a $\mathrm{SiH}_{4}$ flow rate of $10 \mathrm{SCCM}$.

and As ions, monitored during the depth profile for purposes of layer identification, were not quantified but plotted in reference to the logarithmic secondary ion count scale on the right side. The concentrations of $\mathrm{C}$ and $\mathrm{Si}$ were about 1.5 $\times 10^{18}$ and $6 \times 10^{19}$ at. $/ \mathrm{cm}^{3}$, respectively. For comparison, the concentrations of $\mathrm{C}$ and $\mathrm{Si}$ in the films deposited at $1450{ }^{\circ} \mathrm{C}$ were much higher, about $2 \times 10^{19}$ and 3 $\times 10^{20}$ at. $/ \mathrm{cm}^{3}$, respectively. ${ }^{15}$ The $\mathrm{Si}$ and $\mathrm{C}$ concentrations increased sharply at the interface between the $\mathrm{B}_{12} \mathrm{As}_{2}$ film and the $\mathrm{SiC}$ substrate, probably due to the incorporation of $\mathrm{Si}$ and $\mathrm{C}$ into the film from the substrate. Since the carbon and oxygen concentrations were similar among all samples [carbon: $(1-2) \times 10^{18}$ at. $/ \mathrm{cm}^{3}$ and oxygen: (6-8) $\times 10^{18}$ at. $\left./ \mathrm{cm}^{3}\right]$, these concentrations may represent an upper limit of the instrumental background, as measured on $\mathrm{B}_{12} \mathrm{As}_{2}$. The actual carbon and oxygen concentrations may be much lower than these concentrations.

Figure 2 shows the SIMS profiles of $\mathrm{H}, \mathrm{C}, \mathrm{O}$, and $\mathrm{Si}$ impurities in a $1.9 \mu \mathrm{m}$ Si-doped $\mathrm{B}_{12} \mathrm{As}_{2}$ film (S2). The $\mathrm{SiH}_{4}$ flow rate was $10 \mathrm{SCCM}$ for this sample. The Si concentration in the film was about $8 \times 10^{20}$ at. $/ \mathrm{cm}^{3}$, which is one order of magnitude higher than that in the undoped sample S1. Increasing the $\mathrm{SiH}_{4}$ flow rate to 50 and $90 \mathrm{SCCM}$ caused the $\mathrm{Si}$ concentrations to increase in the resulting $\mathrm{B}_{12} \mathrm{As}_{2}$ films. In detail, the $\mathrm{Si}$ concentration is about 3.5 $\times 10^{21}$ at. $/ \mathrm{cm}^{3}$ at a $\mathrm{SiH}_{4}$ doping flow rate of $50 \mathrm{SCCM}$ (sample S3) and is about $7 \times 10^{21}$ at. $/ \mathrm{cm}^{3}$ at a $\mathrm{SiH}_{4}$ doping flow rate of 90 SCCM (sample S4).

RBS/HFS analysis indicated that the above samples had $\mathrm{H}$ concentrations that were less than $5 \times 10^{20}$ at. $/ \mathrm{cm}^{3}$. In atomic percentage concentration, samples examined had hydrogen concentrations in the bulk of the films ranging from $0.1 \%$ to $0.4 \%$. Note that, for sample S4 (the most heavily doped sample at a $90 \mathrm{SCCM} \mathrm{SiH}_{4}$ flow rate), the $\mathrm{Si}$ concentration is about $4.0 \%$, indicating that the silicon has a high solubility in $\mathrm{B}_{12} \mathrm{As}_{2}$. Although the silicon concentration in sample $\mathrm{S} 4$ is high, no additional phases other than $6 \mathrm{H}-\mathrm{SiC}$ and $\mathrm{B}_{12} \mathrm{As}_{2}$ were detected by $\mathrm{x}$-ray diffraction, as shown in Fig. 3. The hydrogen concentration is $0.4 \%$ in sample $\mathrm{S} 4$, which is higher than that in the undoped samples, showing

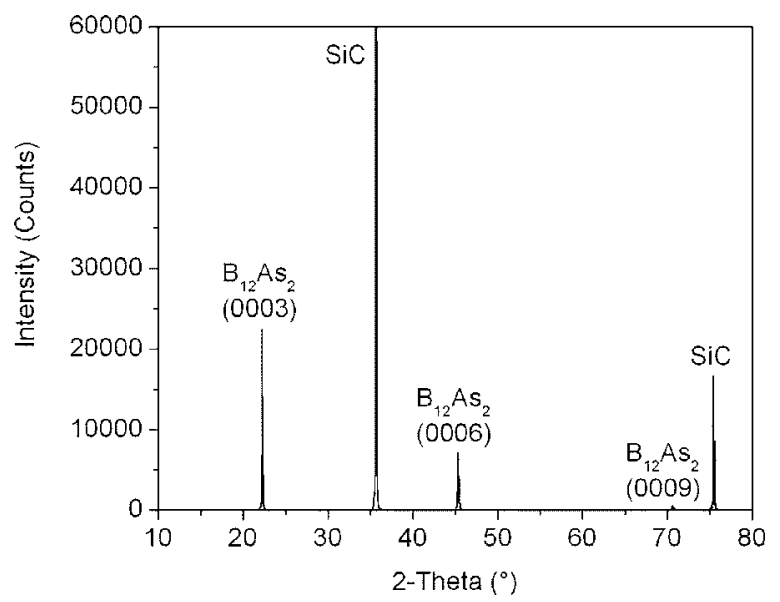

FIG. 3. X-ray diffraction pattern of sample $\mathrm{S} 4$, a Si-doped $\mathrm{B}_{12} \mathrm{As}_{2}$ thin film at a $\mathrm{SiH}_{4}$ flow rate of $90 \mathrm{SCCM}$.

the agreement with the SIMS results that the hydrogen concentration tracks with the silicon concentration.

\section{B. Si-H correlation in $\mathrm{B}_{12} \mathrm{As}_{2}$ films}

Observing that the hydrogen concentration was significantly higher (up to $4 \times 10^{20} \mathrm{at} . / \mathrm{cm}^{3}$ ) in the Si-doped samples than in the undoped sample $\left(3 \times 10^{19}\right.$ at. $/ \mathrm{cm}^{3}$, see Fig. 1), a sample consisting of several layers doped with different $\mathrm{Si}$ concentrations was prepared to further test whether the $\mathrm{Si}$ and $\mathrm{H}$ incorporation rates were correlated. Figure 4 shows the SIMS profiles of $\mathrm{H}, \mathrm{C}, \mathrm{O}$, and $\mathrm{Si}$ impurities in a $0.8 \mu \mathrm{m}$ layer-doped $\mathrm{B}_{12} \mathrm{As}_{2}$ thin film (S5). In this sample the $\mathrm{Si}$ and $\mathrm{H}$ did have a similar concentration versus depth, suggesting that the hydrogen bonds with silicon to form complexes. This phenomenon is similar to the behavior of hydrogen in carbon doped $p$-type GaAs. ${ }^{16,17}$ In $p$-type $\mathrm{GaAs}$, carbon can incorporate with hydrogen to form a $\mathrm{C}-\mathrm{H}$ complex, which neutralizes the electrical activity of the carbon. The silicon and hydrogen concentrations shown in a SIMS profile taken from this sample after annealing at

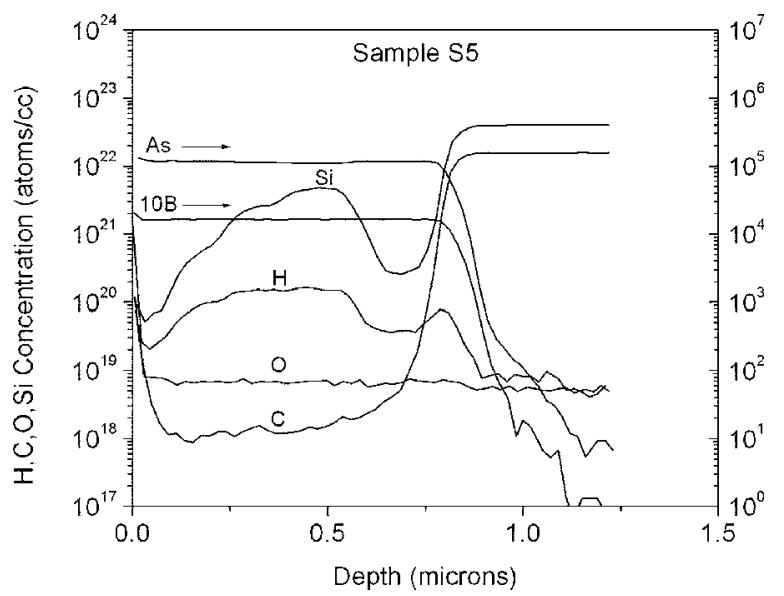

FIG. 4. SIMS profiles of $\mathrm{H}, \mathrm{C}, \mathrm{O}$, and $\mathrm{Si}$ impurities in a layer-doped $\mathrm{B}_{12} \mathrm{As}_{2}$ thin film (see Table I). The hydrogen concentration tracks the silicon concentration. 




FIG. 5. Resistivity of $\mathrm{B}_{12} \mathrm{As}_{2}$ thin films as a function of the silicon concentration, as measured by SIMS.

$600{ }^{\circ} \mathrm{C}$ for $30 \mathrm{~s}$ were identical. The absence of any redistribution or reduction in the hydrogen concentration is particularly noteworthy.

\section{Resistivity reduction by Si doping and by annealing}

As demonstrated, the $\mathrm{Si}$ atomic concentration in $\mathrm{B}_{12} \mathrm{As}_{2}$ films can be controlled by varying the $\mathrm{SiH}_{4}$ doping flow rate. As a consequence of the increased amount of $\mathrm{Si}$ in the films, the resistivity drops. In Fig. 5 the resistivity of four $\mathrm{B}_{12} \mathrm{As}_{2}$ films (doped samples: S2, S3, and S4; undoped sample: S6 as deposited) is plotted as a function of silicon atomic concentrations in the films. The resistivity decreases linearly with increasing silicon concentration with logarithmic scales in both axes. This phenomenon is consistent with the theory that $\mathrm{Si}$ can be used as a $p$-type dopant, i.e., by substituting one $\mathrm{Si}$ atom for one $\mathrm{As}$ atom in $\mathrm{B}_{12} \mathrm{As}_{2}$, the newly formed $\mathrm{Si}-\mathrm{B}$ intericosahedral chain will be an acceptor and one hole will be generated in the internal-bonding states of the neighboring icosahedra of the $\mathrm{Si}-\mathrm{B}$ chain. ${ }^{14}$ Apparently the formed holes in the icosahedral internal-bonding states are responsible for the resistivity reduction as observed above.

To see if the substrate has any influence on the electrical measurements, the sheet resistances of the substrates as received and two samples (S2 and S4) are shown in Table II. The bare SiC substrate has an extremely high sheet resistance. The sheet resistance at the film side is at least one order of magnitude lower than that at the substrate side. Thus it is reasonable to say that there is no parallel conduction from the substrate which could affect the Hall measurement

TABLE II. Sheet resistance of bare substrates as received, $\mathrm{B}_{12} \mathrm{As}_{2}$ films, and substrate sides of the samples.

\begin{tabular}{cccc}
\hline \hline & $\begin{array}{c}\text { Sheet resistance } \\
\text { of substrates } \\
\text { as received }(\Omega / \mathrm{sq})\end{array}$ & $\begin{array}{c}\text { Sheet resistance } \\
\text { on film side } \\
(\Omega / \mathrm{sq})\end{array}$ & $\begin{array}{c}\text { Sheet resistance on } \\
\text { substrate side } \\
(\Omega / \mathrm{sq})\end{array}$ \\
\hline Sample No. & $\sim 3.0 \times 10^{10}$ & $1.3 \times 10^{5}$ & $9.0 \times 10^{6}$ \\
S4 & $\sim 3.0 \times 10^{10}$ & $1.8 \times 10^{5}$ & $2.3 \times 10^{6}$ \\
\hline \hline
\end{tabular}

TABLE III. The resistivity in as-deposited and annealed $\mathrm{B}_{12} \mathrm{As}_{2}$ films.

\begin{tabular}{ccc}
\hline \hline Sample No. & $\begin{array}{c}\text { As-deposited resistivity } \\
(\Omega \mathrm{cm})\end{array}$ & $\begin{array}{c}\text { Annealed resistivity } \\
(\Omega \mathrm{cm})\end{array}$ \\
\hline S6 & $2.4 \times 10^{5}$ & $3.0 \times 10^{4}$ \\
S7 & $1.6 \times 10^{4}$ & 150 \\
S8 & $1.4 \times 10^{3}$ & 22 \\
\hline \hline
\end{tabular}

on the films. It is likely that the samples have some film on the back as well as on the front, which explains why we see large sheet resistance drops on the backside of the substrate after deposition.

Interestingly, the resistivity of $\mathrm{B}_{12} \mathrm{As}_{2}$ films can also be significantly reduced by annealing. To further investigate the observation of Wang et al. ${ }^{13}$ the resistivities of several $\mathrm{B}_{12} \mathrm{As}_{2}$ films samples were measured before and after rapid thermal annealing, as shown in Table III. The resistivity $\rho$ of sample S6 decreased by one order of magnitude after annealing. Two Si-doped samples (S7 and S8) underwent a larger decrease in resistivity by two orders of magnitude after annealing. Thus, the reduction in resistivity occurs whether the samples were undoped or doped with silicon. As stated before, SIMS profiles indicated that there was no $\mathrm{Si}$ or $\mathrm{H}$ reduction or redistribution with annealing, which makes the mechanism for resistivity reduction by annealing unclear.

Due to the high resistivities of the samples, the conductivity type ( $n$ or $p$ ) and the values for the hole mobilities and concentrations are difficult to measure accurately. Most samples were $p$ type but a few were indeterminate. The mobility in all samples was quite low $\left(0.05-2 \mathrm{~cm}^{2} / \mathrm{V} \mathrm{s}\right)$. The low mobility in these samples may be due to the high concentration of structural defects present in these films. ${ }^{11}$ Also, electrical inhomogeneity, possibly due to mixed $n$-type and $p$-type regions, may limit the mobility.

\section{CONCLUSIONS}

The resistivity of $\mathrm{B}_{12} \mathrm{As}_{2}$ on $6 H-\mathrm{SiC}(0001)$ substrates can be controllably varied by changing the concentration of silicon in the films. The resistivity was decreased by roughly four orders of magnitude by increasing the silicon concentration in the films. The resistivity of undoped and Si-doped films decreases by one or two orders of magnitude with rapid thermal annealing in argon at $600{ }^{\circ} \mathrm{C}$ for $30 \mathrm{~s}$. Although the hydrogen concentration increases with and is correlated to the silicon concentration, the change in the resistivity of the samples with annealing could not be attributed to a change in the amount of hydrogen or a change in the spatial distribution of hydrogen concentration with annealing.

${ }^{1}$ G. A. Slack, T. F. McNelly, and E. A. Taft, J. Phys. Chem. Solids 44, 1009 (1983).

${ }^{2}$ D. B. Sullenger, and C. H. L. Kennard, Sci. Am. 215(1), 96 (1966).

${ }^{3}$ O. A. Golikova, Phys. Status Solidi A 51, 11 (1979).

${ }^{4}$ D. Emin, Phys. Today 40, 55 (1987).

${ }^{5}$ T. L. Aselage, D. R. Tallant, J. H. Gieske, S. B. Van Deusen, and R. G. Tissot, The Physics and Chemistry of Carbides, Nitrides and Borides, edited by R. Freer (Kluwer, Dordrecht, 1990), p. 97.

${ }^{6}$ M. Carrard, D. Emin, and L. Zuppiroli, Phys. Rev. B 51, 11270 (1995).

${ }^{7}$ T. L. Aselage and D. Emin, U.S. Patent No. 6,479,919, (9 April, 2001).

${ }^{8}$ R. H. Wang, D. Zubia, T. O'Neil, D. Emin, T. Aselage, W. Zhang, and S. 
D. Hersee, J. Electron. Mater. 29, 1304 (2000).

${ }^{9}$ W. M. Vetter, R. Nagarajan, J. H. Edgar, and M. Dudley, Mater. Lett. 58, 1331 (2004).

${ }^{10}$ R. Nagarajan et al., J. Cryst. Growth 273, 431 (2005).

${ }^{11}$ J. R. Michael, T. L. Aselage, D. Emin, and P. G. Kotula, J. Mater. Res. 20 , 3004 (2005).

${ }^{12}$ Y. Kumashiro, H. Yoshizawa, and K. Shirai, Proceedings 11th International, Symposiumion, Boron, Borides and related Compounds, Tsukuba,
1993, [JJAP Ser. 10, 166 (1994)].

${ }^{13}$ S. H. Wang, E. M. Lysczek, B. Z. Liu, S. E. Mohney, Z. Xu, R. Nagarajan, and J. H. Edgar, Appl. Phys. Lett. 87, 042103 (2005)

${ }^{14}$ D. Emin, J. Solid State Chem. 177, 1619 (2004).

${ }^{15}$ R. Nagarajan, J. H. Edgar, and R. J. Bleiler (unpublished).

${ }^{16}$ B. Clerjaud, F. Gendron, M. Krause, and W. Ulrici, Phys. Rev. Lett. 65, 1800 (1990).

${ }^{17}$ J. Mimila-Arroyo and S. W. Bland, Mod. Phys. Lett. B 15, 585 (2001). 